\title{
Evaluation of Soybean Lines for Edamame (Glycine $\max ($ L.) Merrill) as a Potential Vegetable for Telangana State of India
}

\author{
M. Rajendaar Reddy ${ }^{1 *}$, A. Poshadri' ${ }^{2}$, Sreedhar Chauhan', \\ Y. Prashanth ${ }^{1}$ and R. Uma Reddy ${ }^{3}$ \\ ${ }^{1}$ Agricultural Research Station, Adilabad, India \\ ${ }^{2}$ Krishi Vigyan Kendra, Adilabad, India \\ ${ }^{3}$ Regional Agricultural Research Station, Jagtial, India \\ *Corresponding author
}

\section{Keywords \\ Vegetable soybean, Promising lines, Cooking quality, Nutritional evaluation and sensory evaluation \\ Article Info \\ Accepted: \\ 07 February 2019 \\ Available Online: \\ 10 March 2019}

\section{A B S T R A C T}

Edamame (Glycine $\max$ (L.) Merrill) also called vegetable soybean is an import vegetable and well recognized for health and nutritional benefits in the world. Soybean cultivars with large seed size and high sucrose content are desirable in the production of vegetable soybean, which is the food bean harvested at R6 stage and just before turning to yellow colour. However, the farmers in the state cultivating regular soybean for the past two decades but there is no suitable or improved vegetable soybean cultivars in the state of Telangana, India. In this study, 7 breeding lines were evaluated in replicated field trials for vegetable soybean green pod yield, 100 green seed weight, agronomic traits, cooking quality by sensory attributes and nutritional composition in Agricultural Research statation, Adilabad, Telangana state in 2018. For days to harvest at R6 stage VEG2 taken less days (62days), followed by VEG4 (63 days) and VEG7 taken 104 days to harvest at R6 stage. The trait green pod yield at harvest per plant has recorded maximum in case of genotype VEG 4 (7846 kg/ha) followed by VEG7 $(7551 \mathrm{~kg} / \mathrm{ha})$. In case of 100 green seed weight, the highest mean was observed in VEG 2(75.0g) followed by VEG 4 (74.3g). The genotype VEG 4 is nutritionally equal to regular soybean and superior to other vegetables consumed in the state. Further it was well accepted as a vegetable curry by the panelists in terms of sensory attributes. Further this vegetable soybean may go as supplementary vegetable curry or food source for rural areas of Telangana for nutrition intervention programmes.

\section{Introduction}

In India, soybean (Glycine max) is a major oil seed crop in terms of area, production and economic value. It is mostly grown for the source of edible vegetable oil for human consumption, defatted soy protein products or soy protein extracts (concentrates or isolates) are an important ingredient for several processed foods and protein meal for animal 
feeds (Xiaoyu et al., 2011). In some kind of health foods, baby foods and bakery snacks, defatted soybean flour is an important industrial ingredient in making of premium category foods. Currently India is producing 13.15 million tonnes of soybean from an area of 11.67 Million hectares and the production share accounts $42 \%$ of country's total oil seeds production. The Telangana state in India is producing 0.25 million tonnes of soybean from an area of 0.24 million hectares (Directorate of Economics and Statistics2017). However vegetable soybean (Gglycine $\max (1$.$) Merrill) is relatively new to India,$ although recently directorate of Soybean of ICAR developed NRC105 (INGR10056) vegetable genotype for the table purpose. Vegetable-type soybean, also called edamame and edamame is the Japanese name for a special type of immature soybean that is consumed as a vegetable or snack. It is also known as green soybean or edible soybean in North America and maodou in China (GuoLiang Jiang et al., 2018). Edamame is harvested at the R6 growth stage (Fehr et al., 1971), when the pod cavity is completely filled and the seeds and pod shell are still green in colour and a soft texture (Huang et al., 2014; Saldivar et al., 2010). The regular soybean harvested after full maturity (R8 stage). The tender sweet green seeds have high nutritional values over other legume based vegetables and improved sensory attributes over mature soybean such as sweeter flavor and reduced levels of stachyose and raffinose, resulting in better digestibility (Song et al., 2003). The fermented soymilk from vegetable soybeans showed to be a good food matrix to deliver probiotic bacteria, as well as a soy product with a lower content of non-digestible oligosaccharides (Carolina et al., 2018). Similar to regular dried soybean, vegetable soybean is rich in good quality protein, has a high mineral content and has the potential to prevent some diseases, including cancer, osteoporosis and menopausal symptoms due to its content in is of lavones (Sirisomboon et al., 2007).

Protein Calorie Malnutrition (PCM)' is a major concern in Telangana state in India especially in infants, young children and nursing mothers in rural areas. About $33.1 \%$ children below 5 years under weight (weight for age), $33.3 \%$ children below 5 years under stunted (Height for age) and $67.5 \%$ children less than 5 years are suffering with anaemic problems (NFHS-4 data, 2015-16). Since, many parts of the state producing regular soybean and farmers have the skill set for production of soybean and other regular vegetables. Then the production of vegetable soybean is a good option of crop farming and it also addresses the malnutrion problems at rural areas of Telangana state. The cultivation of vegetable soybean by small-scale farmers and urban agriculture growers is a viable farming option by growing such a high-value niche crop. However, edamame products sold in markets across the United States are mainly imported from China and other Asian countries or regions and are mostly marketed frozen (Guo-Liang Jiang et al., 2018).

Compared with dry soybean as oil seed crop the acreage of edamame grown in the India is much smaller scale and the crop is not yet introduced in the state of Telangana. However, vegetable soybean has better nutrition values than general-purpose soybean (Liu, 1999). In recent decades more and more people have become aware of the health and nutritional benefits of edamame (Messina 1999), and globalization has also provided a platform for international edamame trade. Consequently, there has been a steady increase in edamame market (Guo-Liang Jiang et al., 2018). One of the important reasons for non production of vegetable soybean is that there is a lack of domestically developed or suitable improved edamame 
cultivars in the India and also lack of affordable seed. Therefore, growing vegetable soybean faces challenges and/ or problems. From the point of plant breeding, the major problems include limited genetic resources, lodging, inferior plant structure or type, susceptibility to seed diseases, low yield potential, and shattering, which is important for vegetable soybean seed production.

In view of the above advantages, therefore, it is important to develop edamame cultivars adapted to Telangana state ecological and managemental conditions and to enhance the genetic resources for commercial vegetable soybean production and research. The objective of this study was to evaluate edamame seed breeding lines for vegetable soybean production in order to help identify and develop adapted superior vegetable soybean cultivars with desired nutritional and sensory attributes for the state of Telangana.

\section{Materials and Methods}

A total of 7 Vegetable soybean genotypes of VEG1 to VEG7 were grown in research farm of Agriculture Research Station, Professor Jayashankar Telangana State Agricultural University, Adilabad, Telangana State of India in kharif season of 2018. Most of the genotypes were advanced lines developed by ICAR-Indian Institute of Soybean Research, Indore, India, vegetable soybean/edamame program and derived from different crosses, among one released cultivar (VEG2) was used as check. In a randomized complete block design with three replications, in a black cotton soil with the plot size of 4.05 (sq. m.) having four row plots 3.0 meters long and 1.35 -meter row-spaced were planted at a rate of about 90 plants grown per meter. In accordance with local recommendations, $30 \mathrm{~kg} / \mathrm{ha}$ of nitrogen fertilizer, $60 \mathrm{~kg} / \mathrm{ha}$ of phosphate $\left(\mathrm{P}_{2} \mathrm{O}_{5}\right)$ and $40 \mathrm{~kg} / \mathrm{ha}$ of Potash $\left(\mathrm{K}_{2} \mathrm{O}\right)$ applied to the soil. The crop management was similar to general soybean production, with the insecticides Trizophos + Dichlorovos $(2.0+1.0 \mathrm{ml} / \mathrm{liter}$ water $)$, Emamectin benzoate $(1.0 \mathrm{~g} /$ liter water $)$, Coragen + Saff $(0.3 \mathrm{ml}+2.0 \mathrm{~g} /$ liter water $)$ and Novaluron (1 ml/liter water) applied to control Spodoptera, defoliators, Girdle beetle and Stem fly as needed. The insecticides were purchased from a local store of District Cooperative society and used under an experimental use permit.

The vegetable soybean was sown late in June and harvested at R6 stage or the "green bean" stage (Fehr et al., 1971), in fortnight of September. Soybean vegetable samples of $1 \mathrm{~kg}$ were collected to carry out cooking quality with the help of sensory evaluation and also nutritional composition of freshly harvested vegetable soybean. The traits investigated included plant height (centimetres from the bottom to the top of main stem), Days to harvest vegetable soybean at R6 stage, Green pod yield at harvest $\left(\mathrm{kg} \cdot \mathrm{ha}^{-1}\right)$, Yield of mature seeds $\left(\mathrm{kg} \cdot \mathrm{ha}^{-1}\right)$, the weight (grams) of fresh and dried 100-seeds.

\section{Statistical analysis}

Results were expressed as mean \pm standard deviation. The difference between groups of each parameter was determined using the $t$ test and statistical significance was claimed at $\mathrm{P}<0.05$.

\section{Cooking quality}

\section{Cooking of vegetable soybean}

2 genotypes namely VEG 2 and VEG 4evaluated for cooking quality in pressure cooker with known amount of water and recorded time consumed to cook to the desired quality as against the control dolichos bean quality (Table 1). 
Further, to evaluate the cooking quality and assessing taste profile of vegetable soybean, two regular carries and one cutlet were prepared from vegetable soybean matching to taste profile of South India as shown in Table 2 . The sensory evaluation was conducted with dolichos bean curry as a control sample. The cutlet of green peas was used as control sample to explore vegetable soybean seeds are nutritious substitute food for green peas in cutlet.

\section{Nutritional composition}

The vegetable soybean seed sample which is superior in terms of genetic traits, cooking quality and acceptable sensory attributes was analyzed for moisture, protein $\left(\mathrm{N}^{*} 6.25\right)$, ash, crude fibre and crude fat (AOAC, 1990). Carbohydrate was determined by difference. Selected mineral contents (calcium and Iron) and Vitamin-C were determined by using (AOAC, 2000) methods.

\section{Sensory evaluation}

The sensory assessments were conducted in a KVK, Adilabad laboratory. The panel of 25 members consisted of staff and graduate students of the College of Agriculture, PJTSAU, Jagtial. The panelists were naive to project objectives. Control (Dolichos bean (RND-1), samples (A, B and C) were used in the evaluation. Samples were coded using random three-digit numbers and served with the order of presentation counter-balanced. Panelists were provided with a glass of water and, instructed to rinse and swallow water between samples. They were given written instructions and asked to evaluate the products for Appearance, colour, taste, flavour, mouth feel and overall acceptability, using a 9- point hedonic scale $(1=$ dislike extremely to $9=$ like extremely; Meilgaard $e t$ al., 1999) .

\section{Results and Discussion}

Except harvesting at R6 stage, the vegetable soybean cultivation practices are similar to that of regular dried soybeans. In small farms edamame yield is usually harvested by hands. Pods are ready for harvest when they are close to full size and are bright green (between R6 and R7 growth stage), and pods have filled up to $80-90 \%$ of the pod width (Mentreddy et al., 2002; Basavaraja et al., 2005). It is highly recommended to pre-cool the soybean vegetable immediately after harvesting to reduce the field heat and preserving the freshness as long as possible (Kaiser, and Ernst, 2013). Edamame pods at harvest should have white pubescence; the hilum should be light brown or gray. Two or three seeds must be developed in the pod and pod length must be at least $5 \mathrm{~cm}$ and width $1.4 \mathrm{~cm}$ (Metredy et al., 2002).

There is a wide variation observed between genotypes (Table 3 ) according to Germination (\%), days to flowering, days to maturity, plant height, days to harvest at R6 stage, Green Pod (vegetable soybean) yield, 100 green seed weight at R6 stage, moisture content, yield of mature seeds. Though the check variety (VEG2) having bold seed size but the germination percentage was very low (33\%) when compared to other genotypes and high germination was recorded by genotype VEG7, followed by VEG6 and VEG1. For days to $50 \%$ flowering, least genotype was recorded by VEG 4 (24) followed by VEG 2 (25) and high for VEG 7 (32). For days to maturity genotype VEG4 (88days) and VEG3 (93days) had taken less time to mature where as genotype VEG7 (104 days) taken more days to attain maturity. The genotype VEG3 showed high mean performance (93 days). For plant height highest mean performance was recorded for genotype VEG5 $(61 \mathrm{~cm})$ followed by genotype VEG7 $(60.6 \mathrm{~cm})$ and least for VEG $2(33.0 \mathrm{~cm})$. For days to harvest 
at R6 stage VEG2 taken less days (62days), followed by VEG4 (63 days) and VEG7 taken 104 days to harvest at R6 stage. The trait green pod yield at harvest per plant has recorded maximum in case of genotype VEG 4 (7846 kg/ha) followed by VEG7 (7551 $\mathrm{kg} / \mathrm{ha}$ ) and minimum for VEG 2 (1268kg/ha). Plant height and green pod yield exhibited greater estimates of broad sense heritability than other traits (Table 3). Mebrahtu and Mohamed (2006) reported a greater heritability for plant height and green pod yield as well. In case of 100 green seed weight, the highest mean was observed in VEG 2(75.0g) followed by VEG 4 (74.3g) while least for genotype VEG3 (23.8g). The low yield of mature seeds were recorded in VEG2 $(541 \mathrm{~kg} / \mathrm{ha})$ and highest yields were recorded VEG $4(2815 \mathrm{~kg} / \mathrm{ha})$. The moisture content in freshly harvested green pods of vegetable soybean was ranging from $59.83 \%$ to $74.83 \%$ and highest moisture content recorded in genotype VEG5. Fresh pod yields at harvest and yield of mature seeds were highly correlated, showing a coefficient of determination greater than 0.9 for both phenotypic and genotypic correlation (Table 3 ). This relationship is obvious because more pods means more seed yield, and thus one trait may be used as a selection indicator for the other in breeding. Plant height showed unremarkable or slight correlation with vegetable soybean yields and 100 green send weights. Similar results were the findings of Guo-Liang et al., (2018) Shinde et al., (2013) and Mahbub et al., (2016). Based on the data results showed in table 3 , preliminarily identified 2 promising lines that have desired traits. VEG2 and VEG4 lines exhibited greater acceptable appearance, maturity, green pod yield and 100-green seed weight than the averages of all genotypes evaluated and were superior to all cultivars.

Table.1 Cooking of vegetable soybean genotypes v/s Dolicos bean

\begin{tabular}{|l|c|c|c|}
\hline \multicolumn{1}{|c|}{ Ingredients } & Dolichos bean & VEG 2 & VEG4 \\
\hline Quantity of Vegetable (g) & 175 & 175 & 175 \\
\hline Water (ml) & 310 & 310 & 310 \\
\hline Pressure cooking time (Minutes) & 10 & 12 & 12 \\
\hline
\end{tabular}

Table.2 Formulation of Vegetable soybean v/s dolichos bean curry

\begin{tabular}{|l|c|c|c|}
\hline \multicolumn{1}{|c|}{ Ingredients } & Dolichos bean & VEG 2 & VEG 4 \\
\hline Pressure cooked vegetables (g) & 175 & 175 & 175 \\
\hline Edible Oil (g) & 15 & 15 & 15 \\
\hline Mustard (g) & 0.5 & 0.5 & 0.5 \\
\hline Cumin (g) & 0.5 & 0.5 & 0.5 \\
\hline Onion (g) & 45 & 45 & 45 \\
\hline Ginger and Garlic paste (g) & 5 & 4 & 5 \\
\hline Green chillies No.s & 5 & 4 & 5 \\
\hline Salt (g) & 6 & 5 & 6 \\
\hline Turmeric powder (g) & 1 & 1 & 1 \\
\hline Red chilli (g) & 4 & 3 & 4 \\
\hline Cooking time in minutes & 10 & 10 & 10 \\
\hline
\end{tabular}


Table.3 Genetic variability of vegetable soybean genotypes evaluated in kharif 2018

\begin{tabular}{|c|c|c|c|c|c|c|c|c|c|c|}
\hline Entry Code & $\begin{array}{l}\text { Germina } \\
\operatorname{tion}(\%)\end{array}$ & $\begin{array}{l}\text { Days to } \\
\text { flower }\end{array}$ & $\begin{array}{l}\text { Days to } \\
\text { Maturity }\end{array}$ & $\begin{array}{c}\text { Plant } \\
\text { height } \\
(\mathrm{cm})\end{array}$ & $\begin{array}{c}\text { Days to } \\
\text { picking at } \\
\text { R6 stage }\end{array}$ & $\begin{array}{c}\text { Green pod } \\
\text { yield at } \\
\text { harvest } \\
\text { (kg/ha) }\end{array}$ & $\begin{array}{c}\text { Pod } \\
\text { appearance } \\
\text { at } \\
\text { Harvesting } \\
\text { stage }\end{array}$ & $\begin{array}{c}100 \text { green } \\
\text { seed weight } \\
\text { at harvest } \\
\text { (g) }\end{array}$ & Moisture \% & $\begin{array}{c}\text { Yield of } \\
\text { mature } \\
\text { seeds } \\
(\mathrm{Kg} / \mathrm{ha})\end{array}$ \\
\hline VEG 1 & 86 & 30 & 100 & 43.6 & 73 & 5829 & Glabrous & 32.5 & 60.93 & 2079 \\
\hline VEG2 & 33 & 25 & 90 & 33.0 & 62 & 1268 & Glabrous & 75.0 & 67.96 & 541 \\
\hline VEG3 & 71 & 28 & 93 & 49.1 & 67 & 2581 & Glabrous & 23.8 & 58.05 & 1111 \\
\hline VEG4 & 81 & 24 & 88 & 45.1 & 63 & 7846 & Glabrous & 74.3 & 63.80 & 2815 \\
\hline VEG 5 & 82 & 25 & 99 & 61.0 & 72 & 2825 & Pubescence & 44.2 & 74.83 & 1664 \\
\hline VEG6 & 87 & 31 & 101 & 39.9 & 71 & 3542 & Glabrous & 36.6 & 59.83 & 1871 \\
\hline VEG7 & 90 & 32 & 104 & 60.6 & 74 & 7551 & Glabrous & 26.7 & 61.10 & 2170 \\
\hline C. D. $(5 \%)$ & 3.74 & 2.47 & 3.65 & 8.31 & 3.33 & 714.76 & - & 4.38 & 7.74 & 465.75 \\
\hline C. V. $(\%)$ & 2.7 & 4.8 & 2.1 & 9.7 & 2.6 & 8.8 & & 5.4 & 6.7 & 14.7 \\
\hline
\end{tabular}

Table.4 Sensory evaluation of vegetable soybean**

\begin{tabular}{|l|c|c|c|c|c|c|}
\hline \multicolumn{1}{|c|}{ Samples } & Appearance & Colour & Flavour & Texture & Taste & Overall acceptability \\
\hline Control & $8.6 \pm 0.21$ & $8.5 \pm 0.23$ & $8.1 \pm 0.31$ & $8.9 \pm 0.32$ & $8.8 \pm 0.36$ & $8.9 \pm 0.28$ \\
\hline VEG 2 & $8.3 \pm 0.17$ & $8.7 \pm 0.19$ & $8.0 \pm 0.30$ & $7.7 \pm 0.11$ & $8.4 \pm 0.23$ & $8.0 \pm 0.13$ \\
\hline VEG4 & $8.4 \pm 0.13$ & $8.6 \pm 0.18$ & $8.2 \pm 0.23$ & $7.9 \pm 0.19$ & $8.7 \pm 0.27$ & $8.4 \pm 0.27$ \\
\hline
\end{tabular}

** All the values in Triplicate of analysis and presented as means \pm standard error 
Table.5 Nutrient composition of vegetable soybean (VEG4) V/s other vegetables for 100g*

\begin{tabular}{|c|l|c|c|c|c|c|}
\hline S.No & Nutrients & $\begin{array}{c}\text { Vegetable } \\
\text { Soybean }\end{array}$ & $\begin{array}{c}\text { Dolichos } \\
\text { bean }\end{array}$ & $\begin{array}{c}\text { French } \\
\text { Bean } \\
\text { country) }\end{array}$ & $\begin{array}{c}\text { Broad } \\
\text { beans }\end{array}$ & $\begin{array}{c}\text { Green } \\
\text { Peas }\end{array}$ \\
\hline $\mathbf{1}$ & Energy (kcal) & 442.06 & 93.02 & 23.02 & 25.15 & 83.08 \\
\hline $\mathbf{2}$ & Moisture (\%) (db) & $6.68 \pm 0.6$ & 64.74 & 89.14 & 84.2 & \\
\hline $\mathbf{3}$ & Protein (\%) & $41.54 \pm 0.8$ & 19.83 & 2.49 & 3.85 & 5.42 \\
\hline $\mathbf{4}$ & Fat (\%) & $17.54 \pm 0.2$ & 0.38 & 0.26 & 0.15 & 0.4 \\
\hline $\mathbf{5}$ & Total CHO's (\%) & $29.51 \pm 0.6$ & 2.57 & 2.68 & 2.1 & 14.45 \\
\hline $\mathbf{6}$ & Dietary Fibre (\%) & $12.51 \pm 0.5$ & 12.48 & 4.38 & 8.63 & 5.1 \\
\hline $\mathbf{7}$ & Minerals (\%) & $4.73 \pm 0.3$ & & 1.05 & 1.05 & \\
\hline $\mathbf{8}$ & Iron mg/100g & $8.55 \pm 0.9$ & & 1.25 & 0.94 & 1.47 \\
\hline $\mathbf{9}$ & Calcium mg/100g & $249.8 \pm 0.2$ & & 55.59 & 64.37 & 25 \\
\hline $\mathbf{1 0}$ & Ascorbic acid & $19.62 \pm 0.9$ & & 15.81 & 10.98 & 40 \\
& (mg/100g) & & & & & \\
\hline
\end{tabular}

Further VEG2 and VEG4 promising lines evaluated for sensory attributes after cooking against regular consuming vegetable dolichos bean used as a control sample. The higher pressure cooking time was recorded for vegetable soybean genotypes than the control sample (Table 2). Then the curries prepared were evaluated using 9 point hedonic scale. The mean scores of sensory evaluation showed in table 4 indicating that all the curries and cutlet prepared from vegetable soybean and dolichos bean samples prepared were within the acceptable range, while dolichos bean based curry (control sample) had significantly better appearance $(8.6 \pm 0.0 .21)$, color $(8.5 \pm 0.23)$, flavour $(8.1 \pm 0.31), \quad$ texture $(8.9 \pm 0.32), \quad$ taste $(8.8 \pm 0.36)$ and overall acceptability $(8.9 \pm 0.28)$.

Statistically the curry sample prepared from promising genotype of VEG 4 vegetable soybean had better appearance $(8.4 \pm 0.13)$, color $(8.6 \pm 0.18)$, flavour $(8.2 \pm 0.23)$, texture $(7.9 \pm 0.19)$, taste $(8.7 \pm 0.27)$ and overall acceptability $(8.4 \pm 0.27)$ than compared to other promising lines.
The overall acceptability was mainly based on hardness, mouth feel and taste of curry and cutlet. Whole vegetable soybean curry was found harder due to toughness of husk of the soybean. Majority of the panellists recommended that the curry prepared from vegetable soybean seeds was more acceptable then the whole vegetable soybean like dolichos bean curry.

The cutlet prepared from vegetable soybean was very much accepted than the cutlet prepared from green peas. The genotype VEG 4 which is promising line and well accepted in terms of sensory attribute was chosen for nutritional analysis.

The nutrient contents of $100 \mathrm{~g}$ of promising genotype VEG 4 (41.54 \pm 0.8 protein, and $442.06 \mathrm{kcal} / 100 \mathrm{~g}$ energy and $17.54 \pm 0.2 \mathrm{fat}$ ) fall in line with nutritional composition of regular dried soybean (Karr-Lilienthal et al., 2005) (Table 5). However, vegetable soybean is superior in nutritional composition when compared to regular vegetables (Dolichos bean, French Bean (country) Broad beans and Green Peas) which are consumed regularly in the Telangana state of India. 
In conclusion, the present study revealed that, the promising genotype VEG 4 of vegetable soybean is suitable to cultivate as regular vegetable in the Telangana state. It has the green pod yield potential of $7846 \mathrm{~kg} / \mathrm{ha}$ and 100 green seed weight is $74.3 \mathrm{~g}$. The genotype VEG 4 is nutritionally equal to regular soybean and superior to other vegetables consumed in the state. Further it was well accepted as a vegetable curry by the pane lists in terms of sensory properties. Further this vegetable soybean may go as supplementary vegetable curry or food source for rural areas of Telangana for nutrition intervention programmes.

\section{References}

A.O.A.C. (1990). Official Methods of Analysis of the Association of Official Analytical Chemists, 15th ed. Washington: Arlington, VA.

A.O.A.C (2000). Association of Official Analytical Chemists Official journal 17th ed. Maryland: Gaithersburg, MD.

Basavaraja, G.T., Naidu, G.K., and Salimath, P.M. (2005). Evaluation of vegetable soybean genotypes for yield and component traits. Karnataka Journal of Agricultural Science. 18(1), 27 - 31.

Carolina Battistini, Beatriz Gullón, Erica Sayuri Ichimura, Ana Maria Pereira Gomes, Eliana Paula Ribeiro, Leo Kunigka, José Ubirajara Vieira Moreira, Cynthia Jurkiewicz (2018). Brazilian journal of microbiology 49: 303-309.

Fehr, W.R., C.E. Caviness, D.T. Burmood, and J.S. Pennington (1971). Stage of development descriptions for soybeans, Glycine max (L.). Merrill. Crop Sci. 11:929-931.

Guo-Liang Jiang, Laban K. Rutto, Shuxin Ren , Ronald A, Bowen , Haley Berry and Kyle Epps (2018). Genetic analysis of edamame seed composition and trait relationships in soybean lines. Euphytica: 214:158, 110.

Huang M, Wang Q, Zhang M, Zhu Q (2014). Prediction of color and moisture content for vegetable soybean during drying using hyperspectral imaging technology. J Food Eng. 128:24-30.

Kaiser, C., and Ernst, M. (2013). Edamame. Cooperative extension service. University of Kentucky. $1-4$.

Karr-Lilienthal LK, Kadzere CT, Grieshop CM, Fahey GC Jr (2005) Chemical and nutritional properties of soybean carbohydrates as related to nonruminants: a review. Livest

Liu, K.S. (1999). Soybeans: Chemistry, technology, and utilization. Aspen Publishers, Inc., Gaithersburg, MD.

Longvah T, Anathan R, Bhaskarachary K, and Venkaiah K. 2017. Indian Food Composition Tables 2017. Published by National Institute of Nutrition, ICMR, India.

Mebrahtu, T. and A. Mohamed. 2006. Genetic variation for green pod yield and quality among vegetable soybean genotypes. J. Crop Improv. 16(1/2):113-130.

Meilgaard, M., Civille, G.V. and Carr, B.T. 1999. Sensory Evaluation Techniques. Third edn. CRC Press, Boca Raton.

Mentreddy, S.R., Mohamed, A.I., Joshee, N., and Yaav, A.K. (2002). Edamame: A nutritious vegetable crop. In Trends in new crops and new uses (pp. $432-$ 438). Alexandria: ASHS Press. Prod Sci 97:1-12.

Saldivar X, Wang YJ, Chen P, Mauromoustakos A (2010). Effects of blanching and storage conditions on soluble sugar contents in vegetable soybean. LWT - Food Sci Technol.43:1368-1372.

Sanjiv Kumar, Ranjit Kumar, Seema, A. Dhandapani, N. Sivaramane, PC 
Meena and P. Radhika 2017. Food Consumption Pattern in Telangana State-2017. ICAR-National Academy of Agricultural Research Management, Hyderabad, India.

Shinde S.R., Chavan R.B. and Pawar R.M. (2013). Genetic Divergence in soybean (Glycine $\max$ L. Merrill.) Asian J. of Biosci, 8: 25-228.

Sirisomboon P, Pornchaloempong P, Romphophak T (2007). Physical properties of green soybean: criteria for sorting. J Food Eng.79:18-22.

Solvita Zeipiņa, Ina Alsiņa, Līga Lepse
(2017). Insight in Edamame yield and quality parameters: a review. Research for Rural Development. 2:40-45.

Song JY, An GH, Kim CJ (2003). Color, texture, nutrient contents, and sensory values of vegetable soybeans [Glycine $\max$ (L.) Merrill]as affected by blanching. Food Chem.83:69-74.

Xiaoyu Saldivar, Ya-Jane Wanga, Pengying Chen, Anfu Hou (2011). Changes in chemical composition during soybean seed development. Food Chemistry. 124:1369-1375.

\section{How to cite this article:}

Rajendaar Reddy, M., A. Poshadri, Sreedhar Chauhan, Y. Prashanth and Uma Reddy, R. 2019. Evaluation of Soybean Lines for Edamame (Glycine max (L.) Merrill) as a Potential Vegetable for Telangana State of India. Int.J.Curr.Microbiol.App.Sci. 8(03): 552-560.

doi: https://doi.org/10.20546/ijcmas.2019.803.067 